\title{
Interannual Variability of Energy Flux in Atmospheric Instability Conditions at Pantanal of Mato Grosso-Brazil
}

\author{
Leone Francisco Amorim Curado, José de Souza Nogueira, Luciana Sanches, \\ Marcelo Sacardis Biudes, Thiago Rangel Rodrigues \\ Programa de Pós-Graduação em Física Ambiental-UFMT, Brazil \\ Email: leone@pgfa.ufmt.br
}

Received July 25, 2012; revised August 27, 2012; accepted September 7, 2012

\begin{abstract}
The energy balance partitions in wetlands have gained notoriety due to the dynamics and importance of these areas for regional and local climate. Thus, the study was conducted about seasonal and interannual behavior energy fluxes, as well as the influences of the conditions of atmospheric stability and instability. The results showed highest fluxes happened in instability atmospheric conditions. The fluxes of latent and sensible heat showed seasonal variation, indicating that the water availability in the atmosphere has influence on the site energy partition, but the interannual patterns remained similar during the two years of study.
\end{abstract}

Keywords: Latent Heat; Sensible Heat; Energy Partition; Wetlands

\section{Introduction}

The flood pulse is considered the driving force of the Pantanal and the intensification of the season of dry and wet seasons are the result of multi-annual fluctuations in water level that influence the limnological seasonal characteristics, ecological and biological [1]. October months are the rains begin and it finish between February and May, July and August are characterized as dry months in this region, often causing hidric stress to the plants [2].

Vochysiadivergens is considered an invasive species in Pantanal having a good adapting in flood area. This species incursion in the Pantanal happened in the early $70 \mathrm{~s}$, after the end of an intense and multi-annual period of dry [3]. In not flooded areas the presence of Vochysiadivergens is rare or absent, but present a better development in newly sedimented areas along rivers [4]. In wetlands, there is no problem with this species, but when it reaches the highest parts of Pantanal and advancing toward fields forming forests, it becomes a problem, because it occupies Pasture areas [5].

The apparent cause of the spread of the species in the region may be related to the alternation of major floods and droughts that occur in the Pantanal and also by deforestation caused by livestock farmers in the region, increasing the area available for the plant to establish. These factors can cause shrinkage of native vegetation and increases in populations of this species, giving the vegetation an irregular character in time and space than may lead to short and medium term changes in Pantanal region climate [3].

The flux of latent and sensible heat can be obtained by micrometeorological methods, direct and indirect (estimated), the last one having the advantage of not altering the environment. For direct measurement methods has the eddy covariance system, which takes into consideration the fluctuation of the concentration of water vapor, temperature and fluctuation of wind speed to calculateing the flux and latent heat sensitive respectively [6,7]. The advantage of using direct measures is that small fluctuations in very low intervals of time are obtained, the disadvantage is the value for the acquisition of the equipment.

The LE and $\mathrm{H}$ quantification by Bowen ratio method have been widely used in the last decade, for determining the energy balance in many studies about the energy dynamics of forest and the management availability of water for certain crops by evapo transpiration estimated by the latent heat flux [8-12].

The atmospheric stability can be defined as a condition in which atmospheric air upward movements are absent or permanently inhibited, whereas the condition of instability is defined as the atmospheric state in which prevail the vertical movements. The characterization of these atmospheric conditions is realized according to the temperature distribution of air, i.e., an air layer is considered stable or unstable depending on the value of vertical temperature gradient observed in the layer. It should also consider the situation in which the vertical temperature 
gradient in the atmospheric layer coincides with the rate dry adiabatic. In such condition, the air parcel to ascend or descend will always have the same temperature of the medium that it surrounds, without resistance nor furthering of the vertical movement of the air layer, featuring neutral atmospheric condition [13].

The objective of this work was to study the seasonal behavior of the energy fluxes for stability and instability atmospheric conditions in an area of Vochysiadivergens at Pantanal of Mato Grosso-Brazil.

\section{Materials and Methods}

\subsection{Study Area}

The study was conducted in an area located in the Private Reserve of Natural Heritage-PRNH SESC_-Pantanal, in Barão de Melgaço city-MT, distant $160 \mathrm{~km}$ from Cuiabá-MT where a micrometeorological tower was installed at $32 \mathrm{~m}$ in height $\left(16^{\circ} 39^{\prime} 50^{\prime \prime} \mathrm{S}, 56^{\circ} 47^{\prime} 50^{\prime \prime} \mathrm{W}\right)$ and $120 \mathrm{~m}$ level. This area has a mono-dominate vegetation of Cambará (Vochysiadivergens, Phol), Known locally as cambarazal, with canopy heights ranging from 28 to $30 \mathrm{~m}$ (Figure 1).

\subsection{Measurements}

The net radiation was measured for one net radiometer (Kipp\&Zonen Delft, Inc., Holland), and the heat flux in soil was measured by two fluxímeters (HFT-3.1, REBS, Inc., Seattle, Washington) installed at $0.05 \mathrm{~m}$ e $0.25 \mathrm{~m}$ depth. The gradients of temperature and humidity were estimated by two thermohygrometer (HMP 45 C, Vaisala, Inc., Helsinki, Finland) installed at $33.7 \mathrm{~m} \mathrm{e} 37.7 \mathrm{~m}$ height in micrometeorological tower.

\subsection{Methods}

Atmospheric stability $(\xi)$ was calculated using two methods (Equations (1) and (2)).

$$
\xi=-\frac{0,4 g z H}{\rho c_{p} T_{k} u^{* 3}}
$$

where, $\mathrm{g}$ is the gravitational acceleration $\left(9.8 \mathrm{~ms}^{-1}\right), T_{k}$ is the air temperature $(K), u^{*}$ is the velocity of air friction $\left(\mathrm{ms}^{-1}\right), \rho$ is the air density $\left(1.292 \mathrm{~kg} \cdot \mathrm{m}^{-3}\right), c_{p}$ is the specific heat of the humid air $\left(1013 \mathrm{Jkg}^{-1} \cdot \mathrm{C}^{-1}\right), \mathrm{H}$ is the sensible heat flux where $z$ is the height was measured wind speed.

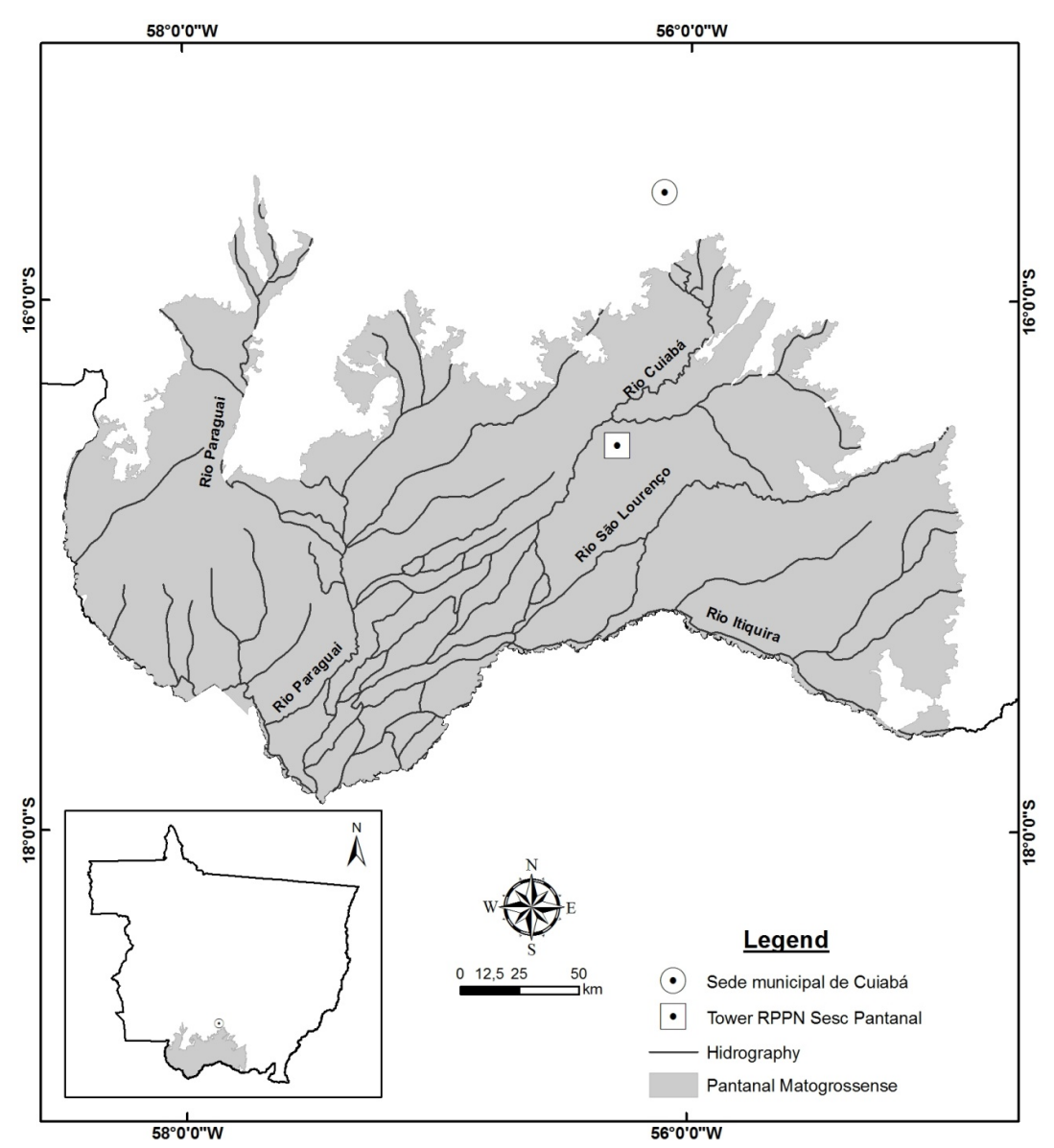

Figure 1. Localization of the micrometeorological tower in the RPPN-SESC Pantanal in MatoGrosso-Brazil. 
The sensible $(\mathrm{H})$ and latent (LE) heat fluxes were calculated according to Equations (2) and (3), respectively.

$$
\begin{gathered}
H=\left(R_{n}-G\right)\left(\frac{\beta}{\beta+1}\right) v \\
L E=\left(\frac{\left(R_{n}-G\right)}{\beta+1}\right)
\end{gathered}
$$

Where $R_{n}$ is net radiation, $G$ is the soil heat flux and $\beta$ is the Bowen ratio, given by:

$$
\beta=\gamma \frac{\Delta T}{\Delta e}
$$

where $\Delta \mathrm{t}$ is difference temperature between two levels $\left({ }^{\circ} \mathrm{C}\right)$, the difference $\Delta e$ pressure of water vapor between two levels $(\mathrm{kPa})$ and the constant $\gamma$ psychometric $(0.0626$ $\left.\mathrm{kPaC}^{-1}\right)$.

\section{Results and Discussion}

\subsection{Seasonality of Weather Condition and Patterns of Latent and Sensible Heat Flux}

Table 1 shows the daily average values of atmospheric conditions (stability and instability) and the latent heat and sensible in the study area.

According to Table 1, it was noted that the highest values of the latent heat and sensible occur with atmospheric in stability, which is because in unstable conditions conducive to turbulence that is the most favorable condition for energy transferring and matter between surface and atmosphere.

The daily average values of seasonal latent heat in the rainy season were higher than in the dry, which also resulted in an increase in the sensible heat flux during the dry period, indicating that the water content due to the precipitation region is a factor determining the amount of energy from the sun which is used to evaporate the water and increased temperature.

This conversion of solar energy into latent and sensible heat is critical for the regulation of ecosystems. According to [14], temperature and humidity conditions within and above a forest are the result of transmission and absorption of solar energy on the surface of the canopy, its conversion into sensible and latent heat and the allocation of light and heat in a forest.

The average daily values of atmospheric conditions showed that both stability and instability remained approximately the same values in both periods (rainy and dry) during the two years studied (2007 and 2008), which indicates a weather regulation in the region of the study.
Table 1. showsthe daily average values of atmospheric cond-

\begin{tabular}{|c|c|c|c|c|}
\hline & & & 2007 & 2008 \\
\hline \multirow[t]{18}{*}{ Wetseason } & Instability & maximum & -0.11 & -0.22 \\
\hline & & minimum & -0.61 & -0.60 \\
\hline & & mean & -0.40 & -0.39 \\
\hline & Stability & maximum & 0.16 & 0.09 \\
\hline & & minimum & -0.01 & -0.01 \\
\hline & & mean & 0.05 & 0.03 \\
\hline & LE_-Unstable & maximum & 547.04 & 454.49 \\
\hline & & minimum & 51.02 & -41.08 \\
\hline & & mean & 306.42 & 280.57 \\
\hline & LE-Stable & maximum & 94.74 & 109.05 \\
\hline & & minimum & -34.82 & -21.6 \\
\hline & & mean & 0.3 & 15.94 \\
\hline & $\mathrm{H}$-Unstable & maximum & 111.54 & 107.94 \\
\hline & & minimum & 9.72 & -6.82 \\
\hline & & mean & 59.73 & 61.48 \\
\hline & $\mathrm{H}-$ Stable & maximum & 18.54 & 22.31 \\
\hline & & minimum & -7.47 & -3.36 \\
\hline & & mean & 0.76 & 3.96 \\
\hline \multirow[t]{18}{*}{ Dryseason } & Instability & maximum & -0.18 & 0.15 \\
\hline & & minimum & -0.57 & -0.62 \\
\hline & & mean & -0.37 & -0.36 \\
\hline & Stability & maximum & 0.09 & 0.11 \\
\hline & & minimum & $-0,02$ & -0.01 \\
\hline & & mean & 0.01 & 0.02 \\
\hline & LE_-Unstable & maximum & 348.47 & 352.96 \\
\hline & & minimum & -7.4 & -46.01 \\
\hline & & mean & 234.02 & 216.03 \\
\hline & LE-Stable & maximum & 60.42 & 77.23 \\
\hline & & minimum & -39.93 & -37.91 \\
\hline & & mean & 0.57 & 4.9 \\
\hline & $\mathrm{H}$-Unstable & maximum & 118.83 & 149.26 \\
\hline & & minimum & -1.41 & -7.76 \\
\hline & & mean & 58.57 & 66.02 \\
\hline & $\mathrm{H}-$ Stable & maximum & 15.68 & 23.06 \\
\hline & & minimum & -15 & -14.91 \\
\hline & & mean & 0.33 & 0.7 \\
\hline
\end{tabular}
itions (stabilityand instability) and the latent heat and sensible in the study area.

\subsection{Inter-Annual Variability of Weather Conditions and Patterns of Latent and Sensible Heat in the Rainy Season}

The values in Table 1and Figure 2 indicate that the energy converted into latent heat flux was on average higher than the energy converted into heat sensitive within two years of study during the rainy season, except on condition of stability of the year 2007, which indicates that the amount of water present in the atmosphere is a 
regulating agent of the ecosystem in question, this result was found by [2].

Another important factor is that in analyzing inter-annual patterns in atmospheric conditions (stability and instability) were between one year and one which also occurred with the latent heat and sensible, who have followed these conditions, with higher instability values than the stability in the two years of study, thus indicating that during the wet season of 2007 and 2008 standards in these variables kept the same.

\subsection{Inter-Annual Variability of Weather Conditions and Patterns of Latent and Sensible Heat in the Dry Season}

According to Figure 3, it was noted that as in the rainy period between the study period, in the dry most of the available energy to the ecosystem was converted into latent heat, showing that even in periods with little or no precipitation the evaporative requirement is relatively high compared with the sensible heat flux, demonstrating that the latent heat flux is the main component of the energy balance in this region.

The same to the rainy season, the highest values of latent heat flux and sensible culminated with the conditions of atmospheric instability, which as already mentioned in Section 3.1, this condition favors the turbulence that promotes the energy transfer between the surface and atmosphere through the fluxes of latent and sensible.

Another important factor is the greater variability of the data sensible and latent heat flux in the dry season than in rainy season in both years studied, this is caused

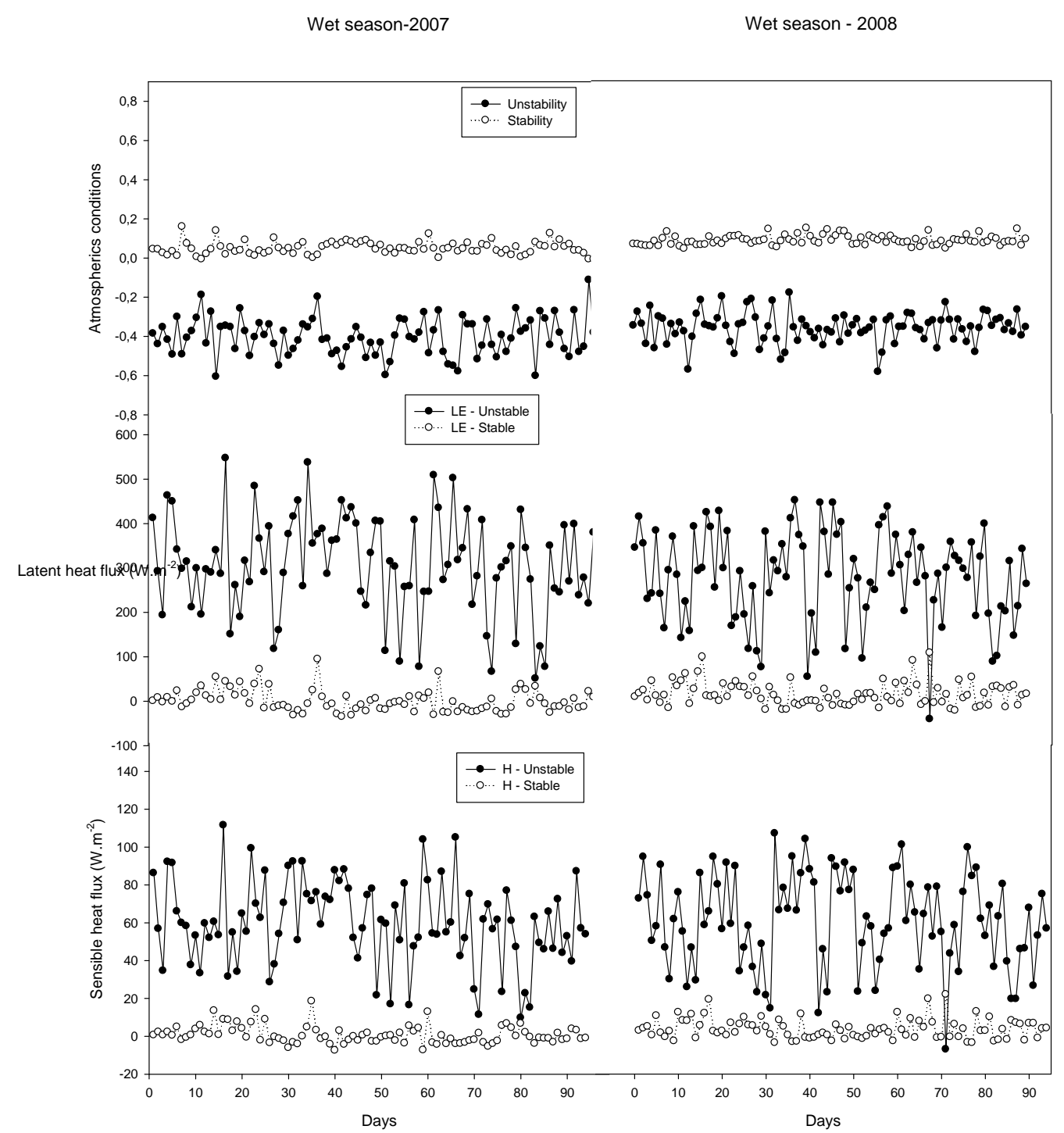

Figure 2. Daily average values of conditions atmospheric stability, atmospheric instability and flux of latent and sensible heat during the wet season in the years 2007 and 2008. 


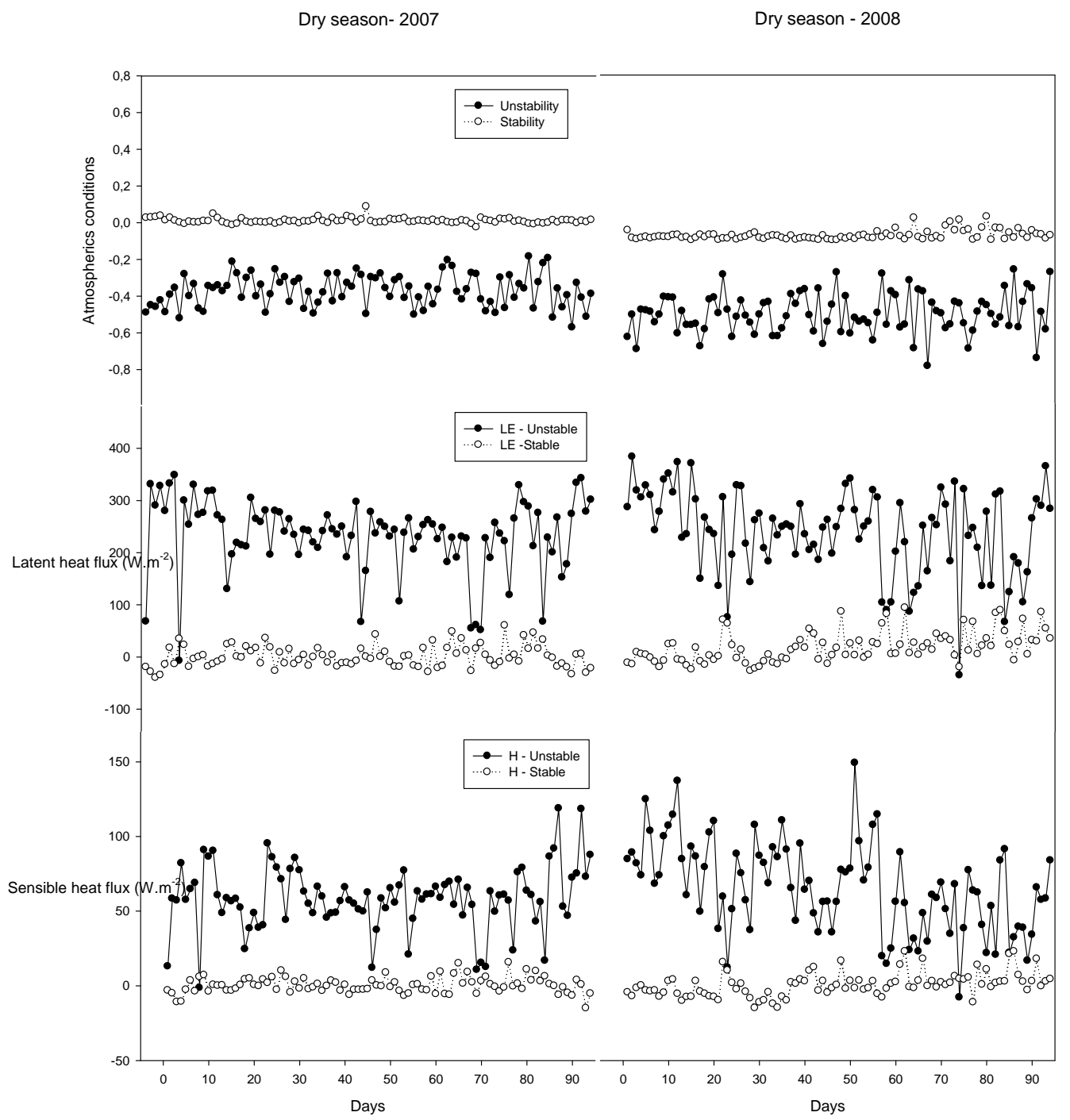

Figure 3. Daily average values of conditions atmospheric stability, atmospheric instability and flux of latent and sensible heat during the dry season in the years 2007 and 2008.

by the fact that there is greater variation in temperature in the region due to low water content in the atmosphere and also for this period include the winter season than in the southern hemisphere occurs between June and September, which causes abrupt changes in temperature, thus causing a greater variability in the energy flux data. This greater variability in temperature data during the dry period is described in [15].

Lower values of LE during the dry period can be explained by lower temperatures, drier air and lower radiation (winter solstice), and is a limiting feature of this water at this station canopy. During the dry season, there is a decline in water content in soil and can limit evaporation and water availability for plant root surface [16]. However, higher values of evapotranspiration in the wet season were related to increased rainfall and flood water depth [17].
Lower values of LE, during the dry period, were also reported in the Cerrado and Amazon transition forestsavanna in the Midwest, while in tropical rain forests located in Manaus, Santarem and Rondonia citywere reported lower values of evapotranspiration during the wet season $[18,19]$.

Thus, the partition of energy in the Pantanal regions is strongly influenced by water availability in soil and atmosphere and the conditions of instability and stability atmospheric.

\section{Conclusions}

Latent and sensible heat flux was influenced by weather conditions in the region, and the condition of instability caused the highest values of energy flow by favoring the transport of energy between the surface and atmosphere through turbulence. 
The most of available energy were converted into latent heat in the two years of study, showing that the water content is a regulatory agency in the region.

The variables studied (instability, stability, latent heat and sensible heat) showed similar patterns for the same period, the interannual analysis.

Water availability and season influenced the partitioning of energy of site.

\section{Acknowledgements}

The authors thank Coordenação de Aperfeiçoamen to de Pessoal do Ensino Superior(CAPES), Conselho Nacional de Desenvolvimento Científico e Tecnológico (CNPq) for Scholarship and Fundo de Amparo a Pesquisa do Estado de Mato Grosso (FAPEMAT) through the Support Program for Centers of Excellence (PRONEX) for financial support to the research project process No. 823971/ 2009.

\section{REFERENCES}

[1] W. J. Junk, P. B. Bayley and R. E. Sparks, "The Flood Pulse Concept in River-Floodplain Systems," Proceedings of the International Large River Symposium (LARS), Canadian Special Publication of Fisheries and Aquatic Sciences, Ottawa, 1989, pp. 110-127.

[2] M. S. Biudes, J. S. Campelo Jr., J. S. Nogueira and L. Sanches, "Estimativa do Balanço de Energia Cambarazal e Pastagem no Norte do Pantanal Pelo Método da Razão de Bowen," Revista Brasileira de Meteorologia, Vol. 24, No. 2, 2009, pp. 135-143. doi:10.1590/S0102-77862009000200003

[3] W. J. Junk, "Long-Term Environmental Trends and the Future of Tropical Wetlands," Environmental Conservation, Vol. 29, No. 4, 2002, pp. 414-435. doi: $10.1017 / \mathrm{S} 0376892902000310$

[4] C. N. Da Cunha and W. J. Junk, "Year-to-Year Changes in Water Level Drive the Invasion of Vochysia divergens in Pantanal Grasslands," Applied Vegetation Science, Vol. 7, No. 1, 2004, pp. 103-110.

doi:10.1658/1402-2001(2004)007[0103:YCIWLD]2.0.C $\underline{\mathrm{O} ; 2}$

[5] S. A. Santos and C. Costa, "Estimativa da Radiação de Onda Longa Atmosférica no Pantanal sul Mato-Grossense Durante os Períodos Secos de 1999 e 2000," 2006 Revista Brasileira de Meteorologia, Vol. 21, No. 3b, 2006, pp. 398-412.

[6] D. D. Baldocchi and T. P. Meyers, "On Using EcoPhysiological, Micrometeorological and Biogeochemical Theory to Evaluate Carbon Dioxide, Water Vapor and Trace Gas Fluxes over Vegetation: A Perspective," Agricultural and Forest Meteorology, Vol. 90, No. 1-2, 1998, pp. 1-25. doi:10.1016/S0168-1923(97)00072-5

[7] N. Priante-Filho, G. L. Vourlitis, M. M. S. Hayashi, J. S. Nogueira, J. H. Campelo Jr., P. C. Nunes, L. S. Souza, E. G. Couto, W. Hoeger, F. Raiter, J. L. Trienweiler, E. J. Miranda, P. C. Priante, C. L. Fritzen, M. Lacerda, L. C. Pereira, M. S. Biudes, G. S. Suli, S. Shiraiwa, S. R. Paulo and M. Silveira, "Comparison of the Mass and Energy Exchange of a Pasture and a Mature Transitional Tropical Forest of the Southern Amazon Basin during a Seasonal Transition," Global Change Biology, Vol. 10, No. 5, 2004, pp. 863-876. doi:10.1111/j.1529-8817.2003.00775.x

[8] I. Alves and L. S. Pereira, "Modelling Surface Resistance from Climatic Variables?" Agricultural Water Management, Vol. 42, No. 3, 2000, pp. 371-385. doi:10.1016/S0378-3774(99)00041-4

[9] M. M. S. Hayashi, J. H. Campelo Jr., N. P. Filho, J. S. Nogueira and G. L. Vourlitis, "Balanço de Energia da Crotalaria juncea L. no Período Seco e no Período Úmido do Ano, em Condições de Cerrado," Revista Brasileira de Agrometeorologia, Vol. 10, No. 2, 2002, pp.197-205.

[10] J. R. S. Lima, A. C. D. Antonino, W. A. Soares, E. Borges, I. F. Silva and C. A. B. O. Lira, "Balanço de Energia em um Solo Cultivado Com Feijão Caupí no Brejo Paraibano," Revista Brasileira de Engenharia Agrícola e Ambiental, Vol. 9, No. 4, 2005, pp. 527-534. doi:10.1590/S1415-43662005000400014

[11] S. P. Chen, J. Q. Chen, G. H. Lin, W. L. Zhang, H. X. Miao, L. Wei, J. H. Huang and X. G. Han, "Energy Balance and Partition in Inner Mongolia Steppe Ecosystems with Different Land Use Types," Agricultural and Forest Meteorology, Vol. 149, No. 11, 2009, pp. 1800-1809. doi:10.1016/j.agrformet.2009.06.009

[12] T. W. Giambelluca, F. G. Scholz, S. J. Bucci, F. C. Meinzer, G. Goldstein, W. A. Hoffmann, A. C. Franco and M. P. Buchert, "Evapotranspiration and Energy Balance of Brazilians Savannas with Contrasting Tree Density," Agricultural and Forest Meteorology, Vol. 149, No. 8, 2009, pp. 1365-1376. doi:10.1016/j.agrformet.2009.03.006

[13] R. L. Vianello and A. R. Alves, "Meteorologia Básica e Aplicações," Federal University of Viçosa (UFV), Viçosa, 2004.

[14] T. Motzer, "Micrometeorological Aspect of a Tropical Mountain Forest," Agriculturaland Forest Meteorology, Vol. 135, No. 1-4, 2005, pp. 230-240. doi:10.1016/j.agrformet.2005.11.019

[15] L. F. A. Curado, T. R. Rodrigues, M. S. Biudes, S. R. De Paulo, I. J. C. De Paulo and J. S. Nogueira, "Estimativa Sazonal da Emissividade Atmosférica Através da Equação de Brutsaert no Norte do Pantanal Mato-Grossense," Ciência e Natura, Vol. 33, No. 2, 2011, pp. 167-180.

[16] F. C. Meinzer, G. Goldstein, A. C. Franco, M. Bustamante, E. Igler, P. Jackson, L. Caldas and P. W. Rundel, "Atmospheric and Hydraulic Limitations on Transpiration in Brazilian Cerrado Woody Species," Functional Ecology, Vol. 13, No. 2, 1999, pp. 273-282. doi:10.1046/j.1365-2435.1999.00313.x

[17] L. Sanches, M. C. Alves, J. S. Campelo Jr., J. S. Nogueira and H. J. Dalmagro, "Estimativa do Coeficiente PriestleyTaylor em Floresta Monodominante Cambarazal no Pantanal," Revista Brasileira de Meteorologia, Vol. 25, No. 4, 2010, pp. 448-454. doi:10.1590/S0102-77862010000400004

[18] H. R. Rocha, A. O. Manzi, O. M. Cabral, S. D. Miller, M. L. Goulden, S. R. Saleska, N. R.-Coupe, S. C. Wofsy, L. 
S. Borma, P. Artaxo, G. Vourlitis, J. S. Nogueira, F. L. Cardoso, A. O D. Nobre, B. Kruijt, H. C. Freitas, C. Von Randow, R. G. Aguiar and J. F. Maia, "Patterns of Water and Heat Flux across a Biome Gradient from Tropical Forest to Savanna in Brazil," Journal of Geophysical Research, Vol. 114, 2009, Article ID: G00B12. doi:10.1029/2007JG000640
[19] A. C. Miranda, H. S. Miranda, J. Lloyd, J. Grace, R. J. Francey, J. A. Macintryre, P. Meir, P. Riggan, R. Lockwood and J. Brass, "Fluxes of Carbon, Water, and Energy over Brazilian Cerrado: An Analysis Using Eddy Covariance and Stable Isotopes," Plant, Cell and Environment, Vol. 20, No. 3, 1997, pp. 315-328. doi:10.1046/j.1365-3040.1997.d01-80.x 